\title{
Efficacy of vinblastine in central nervous system Langerhans cell histiocytosis: a nationwide retrospective study
}

Sophie Ng Wing Tin ${ }^{1}$, Nadine Martin-Duverneuil², Ahmed Idbaih, Catherine Garel ${ }^{3}$, Maria Ribeiro ${ }^{4}$, Judith Landman Parker ${ }^{5}$, Anne-Sophie Defachelles ${ }^{6}$, Anne Lambilliotte ${ }^{7}$, Mohamed Barkaoui ${ }^{8}$, Martine Munzer ${ }^{9}$, Martine Gardembas ${ }^{10}$, Jean Sibilia ${ }^{11}$, Patrick Lutz ${ }^{12}$, Renato Fior ${ }^{13}$, Michel Polak ${ }^{14}$, Alain Robert ${ }^{15}$, Olivier Aumaitre ${ }^{16}$, Dominique Plantaz ${ }^{17}$, Corinne Armari-Alla ${ }^{17}$, Thierry Genereau ${ }^{18}$, Perrine Marec Berard ${ }^{19}$, Ghislain Nokam Talom ${ }^{20}$, Jean-Loup Pennaforte ${ }^{21}$, Hubert Ducou Le Pointe ${ }^{3}$, Marie-Anne Barthez ${ }^{22}$, Gérard Couillault ${ }^{23}$, Julien Haroche ${ }^{24}$, Karima Mokhtari ${ }^{25}$, Jean Donadieu ${ }^{5,8}$ and Khê Hoang-Xuan ${ }^{1 *}$, for the French LCH study group

\begin{abstract}
Background: Vinblastine (VBL) is the standard treatment for systemic Langerhans cell histiocytosis (LCH), but little is known about its efficacy in central nervous system (CNS) mass lesions.

Methods: A retrospective chart review was conducted. Twenty patients from the French LCH Study Group register met the inclusion criteria. In brief, they had CNS mass lesions, had been treated with VBL, and were evaluable for radiologic response.

Results: The median age at diagnosis of LCH was 11.5 years (range: 1-50). Intravenous VBL 6 mg/m² was given in a 6 -week induction treatment, followed by a maintenance treatment. The median total duration was 12 months (range: 3-30). Eleven patients received steroids concomitantly. Fifteen patients achieved an objective response; five had a complete response (CR: 25\%), ten had a partial response (PR: 50\%), four had stable disease (SD: 20\%) and one patient progressed (PD: 5\%). Of interest, four out of the six patients who received VBL without concomitant steroids achieved an objective response. With a median follow-up of 6.8 years, the 5-year event-free and overall survival was $61 \%$ and $84 \%$, respectively. VBL was well-tolerated and there were no patient withdrawals due to adverse events.
\end{abstract}

Conclusion: VBL, with or without steroids, could potentially be a useful therapeutic option in LCH with CNS mass lesions, especially for those with inoperable lesions or multiple lesions. Prospective clinical trials are warranted for the evaluation of VBL in this indication.

\section{Background}

Langerhans cell histiocytosis $(\mathrm{LCH})$ is a rare disease characterized by an accumulation of Langerhans cells [1]. Clinical presentation ranges from isolated benign localization to multisystemic aggressive lesions. Although it is most common in children under 15 years of age, it may occur at any age [2-4]. Central nervous system (CNS) complications of LCH occur in 1-11\% of patients [4-6]

\footnotetext{
* Correspondence: khe.hoang-xuan@psl.aphp.fr

'APHP-UPMC, Service de neurologie 2-Mazarin, Groupe Hospitalier PitiéSalpêtrière, Paris, France

Full list of author information is available at the end of the article
}

and can be subdivided clinically into two subtypes, each corresponding with a distinct pathophysiology. The first type is the 'neurodegenerative-like' form, characterized by neuronal cell loss and a progressive cerebellar ataxia, frequently combined with pyramidal syndrome and cognitive dysfunction [7-12]. The second type is the tumoral or mass lesions-type presenting as unique or multiple contrast-enhancing space-occupying lesions [13-16]. In this latter form, the lesions can be located anywhere in the CNS but are most commonly found in the hypothalamo-pituitary region. Optimal treatment for $\mathrm{LCH}$ with CNS mass lesions is not yet well defined, and depends on

\section{Biomed Central}


the site of the disease [5]. Vinblastine (VBL) chemotherapy is the standard treatment for aggressive systemic $\mathrm{LCH}$ [17], but little is known about its efficacy in LCH with CNS mass lesions. In order to evaluate the efficacy and safety of VBL, we retrospectively studied patients from the French LCH register who had received VBL for LCH with CNS mass lesions.

\section{Methods}

Patients with CNS mass lesions were identified from the French LCH Study Group register. This database was initially created for a retrospective study of patients with LCH between 1983 and 1993, but from 1994 enrolment into the database was conducted prospectively. Since 2008 this collection of data has been recognized as a national register by the French health authorities and has been verified against multiple separate sources [18]. The database has been declared to the French computer watchdog authorities (Comité Consultatif pour le Traitement de l'Information en matière de Recherche pour la Santé [CCTIRS] and Commission Nationale Informatique et Liberté [CNIL]), and the patient must provide informed consent to be included in the register. Data monitoring, based on medical charts, was conducted by a clinical research associate who visited each center. Patients listed in the register were included in the study if they had: i) LCH with CNS mass lesions defined as the presence of a contrast-enhancing space-occupying CNS lesion occurring in a patient with either proven systemic $\mathrm{LCH}$ or who meets the pathologic criteria for $\mathrm{LCH}$ on CNS biopsy according to the histiocyte society (CD1a positive cells or Birbeck granules)[19]; ii) received treatment with VBL either as initial or salvage treatment; and iii) had measurable disease with lesions visible after contrast-enhanced magnetic resonance imaging (MRI) and were evaluable for tumor response (i.e. availability of pre and post-therapeutic MRIs for review). Imaging studies performed before and after treatment with VBL were reviewed independently by three investigators (NMD, SNWT and CG).

The primary endpoint was the radiologic response to VBL therapy. Response was assessed by determining the product of the two largest perpendicular diameters of the lesion on the axial T1 planes of the MRI scan, as previously reported by Macdonald [20]. A complete response $(\mathrm{CR})$ was defined as complete disappearance of all mass lesions; a partial response (PR) was defined as a greater than $50 \%$ reduction in the size of all measurable mass lesions, and patients must be on stable or reduced doses of corticosteroids and show a stable or improved neurologic status. Progressive disease (PD) was defined as a greater than $25 \%$ increase in the size of measurable mass lesion(s) or as tumor-related neurologic deterioration. Stable disease (SD) was defined as any other clinical status not meeting the criteria for CR, PR, and PD. Secondary endpoints included event-free survival, number of relapses, endocrine sequelae, death and overall survival. Event-free survival was defined as the time from start of VBL treatment until the event (death, relapse or progression), or the date of last examination if no event occurred. Initial failure (PD) was considered as an event and, in this instance, the time-to-event was equal to zero. Relapse was defined as disease progression after an initial favorable response. The Kaplan-Meier method was used to estimate overall survival and event-free survival. The cut-off date for data analysis was November 15, 2010.

\section{Results \\ Patients}

Among 1411 patients from the French LCH Study Group register, 57 were identified with CNS Langerhans cell histiocytic mass lesions. Of these, 37 were excluded: two had been treated only with surgery, four had received 2-chlorodeoxyadenosine (2-cda) as initial therapy, four were under observation, ("watchful waiting"), two had received other chemotherapy and radiotherapy treatments, and the remaining 26 did not have MRI scans accessible for review. The retained 20 patients fulfilled the inclusion criteria of the study, including having received VBL treatment and were evaluable for an objective response. CNS lesions were documented by MRI imaging in all patients, and additionally in 9 patients by CNS mass lesion biopsy to confirm tumor immunohistochemistry.

\section{Patient characteristics}

The main clinical characteristics of the patients are summarized in Table 1 . Of the 20 patients, 12 were female and 8 male. The median age of $\mathrm{LCH}$ diagnosis onset was 11.5 years (range: $1-50$ ) and the median age of neurologic involvement diagnosis was 12 years (range: $3-53$ ). Neurologic diagnosis were simultaneous with the first occurrence of $\mathrm{LCH}$ in 12 patients and occurred during a reactivation in 8 patients (after a median delay of 3.7 years since the first occurrence of $\mathrm{LCH}$ ).

The CNS mass lesions were solitary $(\mathrm{n}=15)$ or multifocal $(n=5)$. Lesions were located solely in the hypothalamo-pituitary region in 14 patients and were solely extrahypothalamic in 4 patients; 2 patients had both hypothalamic and extrahypothalamic lesions. All three patients with brainstem mass lesions were adults. In addition to a mass lesion, three patients had typical bilateral non-enhancing lesions of the cerebellum white matter, which are usually observed in the neurodegenerative form of LCH (patients \#2, \#5 and \#6). Symptoms of CNS disease were linked to the site of the CNS lesions (diabetes insipidus, cognitive impairment, seizures, hemiparesis, 
Table 1 Patient demographic and clinical characteristics

\begin{tabular}{|c|c|c|c|c|c|c|}
\hline Patient & Sex & $\begin{array}{l}\text { Age at diagnosis } \\
\text { of LCH (years) }\end{array}$ & $\begin{array}{l}\text { Age at diagnosis of CNS } \\
\text { involvement (years) }\end{array}$ & $\begin{array}{l}\text { Localisation of CNS } \\
\text { mass lesion }\end{array}$ & $\begin{array}{l}\text { Other sites of } \\
\text { LCH involvement }\end{array}$ & Symptoms \\
\hline 1 & $\mathrm{~F}$ & 10 & 12 & hp & Bone, skin & Diabetes insipidus \\
\hline 2 & $\mathrm{~F}$ & 50 & 53 & $p$ (brainstem) & mastoid & Cerebellar ataxia \\
\hline 3 & $\mathrm{~F}$ & 26 & 28 & $\mathrm{hp}$ & None & $\begin{array}{l}\text { Cognitive impairment, bulimia, } \\
\text { diabetes insipidus }\end{array}$ \\
\hline 4 & $M$ & 9 & 9 & $\mathrm{hp}$ & None & Diabetes insipidus \\
\hline 5 & M & 21 & 34 & $\begin{array}{l}\mathrm{p} \text { (multifocal: frontal and } \\
\text { brainstem) }\end{array}$ & Bone, lung & $\begin{array}{l}\text { Cerebellar ataxia, cranial nerve palsies } \\
\text { hemiparesis, diabetes insipidus }\end{array}$ \\
\hline 6 & $\mathrm{~F}$ & 2 & 3 & $\mathrm{hp}$ & Skin & Diabetes insipidus \\
\hline 7 & M & 41 & 44 & $\mathrm{hp}$ & Lung & $\begin{array}{l}\text { Cognitive impairment, diabetes } \\
\text { insipidus }\end{array}$ \\
\hline 8 & $\mathrm{~F}$ & 3 & 3 & $\mathrm{hp}$ & Skin, bone, thyroid & Diabetes insipidus \\
\hline 9 & $\mathrm{~F}$ & 7 & 7 & $\mathrm{hp}$ & Skin, lung & Diabetes insipidus \\
\hline 10 & $\mathrm{~F}$ & 1 & 10 & $\mathrm{hp}$ & Skin, bone, & Visual field defect \\
\hline 11 & $\mathrm{~F}$ & 4 & 4 & $\mathrm{hp}$ and $\mathrm{m}$ & Bone & Diabetes insipidus \\
\hline 12 & M & 26 & 30 & $\mathrm{hp}$ and $\mathrm{p}$ (brainstem) & $\begin{array}{l}\text { Skin, lung, parotid, } \\
\text { liver }\end{array}$ & Hemiparesis, headaches \\
\hline 13 & M & 35 & 35 & $\mathrm{hp}$ & Bone & Diabetes insipidus \\
\hline 14 & $\mathrm{~F}$ & 15 & 16 & hp & None & Headaches \\
\hline 15 & $\mathrm{~F}$ & 2 & 12 & $\begin{array}{l}\mathrm{p} \text { (multifocal: temporal, } \\
\text { frontal, parietal lobes) }\end{array}$ & Bone, skin & Diabetes insipidus \\
\hline 16 & M & 28 & 28 & $\mathrm{hp}$ & Bone & $\begin{array}{l}\text { Cognitive impairment, diabetes } \\
\text { insipidus }\end{array}$ \\
\hline 17 & $\mathrm{~F}$ & 15 & 15 & hp & None & Visual field defect, diabetes insipidus \\
\hline 18 & M & 1 & 5,5 & hp & Bone, skin & Diabetes insipidus \\
\hline 19 & $\mathrm{~F}$ & 12 & 12,1 & $\mathrm{hp}$ & None & Diabetes insipidus \\
\hline 20 & M & 11 & 11 & $\mathrm{p}$ (cerebellum) & None & Cerebellar ataxia \\
\hline
\end{tabular}

CNS = central nervous system, $\mathrm{F}=$ female, $\mathrm{hp}=$ hypothalamo-pituitary region involvement, $\mathrm{LCH}=$ Langerhans cell histiocytosis, $\mathrm{M}=$ male, $\mathrm{p}=$ parenchymal involvement, $\mathrm{m}=$ meningeal involvement.

cerebellar ataxia, cranial nerve palsies). CNS disease was associated with multisystemic LCH in 13 patients (bone, skin and lung involvement) and isolated in 7 patients. Eighteen patients were previously untreated before VBL therapy, and two patients were previously treated (patient \#10 with steroids and patient \#5 with combination chemotherapy of methotrexate plus etoposide). Intravenous VBL was delivered at a standard dose $\left(6 \mathrm{mg} / \mathrm{m}^{2}\right)$, given once weekly for 6 weeks (induction treatment) followed by a maintenance dose every 3 weeks. All patients received the 6-week induction treatment; the median duration of maintenance treatment was 12 months (range 3-30). Eleven patients were already receiving steroids prior to initiation of VBL or received steroids concomitantly to VBL as part of the chemotherapy regimen (Table 2).

\section{Primary endpoint: response to treatment}

Fifteen patients achieved an objective response, including five complete responses (CR 25\%) and 10 partial responses (PR 50\%); four patients had stable disease (SD $20 \%$ ) and one had progressive disease (PD 5\%). Of interest, four out of the six patients who received VBL but not steroids achieved an objective response $(1 \mathrm{CR}, 3$ PR, 1 SD, 1 PD; Figures 1, 2 and 3). After evaluation of the initial response, the 10 patients with a partial response continued VBL maintenance therapy until the end of the therapy or in one case, until disease progression (Table 2).

\section{Secondary endpoints}

Treatment with VBL was well-tolerated. The most severe adverse events were mild peripheral neuropathy (grade 2; $\mathrm{n}=2$, patients \#10 and \#12) and increased liver enzymes (grade $2 ; \mathrm{n}=2$, patients \#14 and \#16). There were no reports of patients withdrawing from treatment as a result of adverse events.

After a median follow-up of 6.8 years (from VBL-treatment onset), the 2- and 5-year event-free survivals were $67 \%$ and $61 \%$, respectively, with a plateau after 3 years (Figure 4). At the time of analysis, seven patients had relapsed. Details of therapy for relapse are included in Table 2: three patients were retreated with VBL 
Table 2 Response to treatment and outcome

\begin{tabular}{|c|c|c|c|c|c|c|c|c|c|c|}
\hline Patient & $\begin{array}{l}\text { Treatment } \\
\text { duration } \\
\text { (months) }^{\mathrm{a}}\end{array}$ & $\begin{array}{l}\text { Concomitant } \\
\text { steroids (Y/ } \\
\text { N) }\end{array}$ & $\begin{array}{l}\text { Radiologic } \\
\text { response }\end{array}$ & $\begin{array}{l}\text { Change to } \\
\text { therapeutic } \\
\text { regimen after } \\
\text { radiologic } \\
\text { evaluation }(\mathrm{Y} / \mathrm{N}) \\
\text { [details] }\end{array}$ & $\begin{array}{l}\text { Relapse }(\mathrm{Y} / \mathrm{N}) \\
\text { [details] }\end{array}$ & $\begin{array}{l}\text { Treatment for } \\
\text { relapse [details] }\end{array}$ & $\begin{array}{l}\text { Endocrine } \\
\text { sequelae }\end{array}$ & $\begin{array}{l}\text { NDS/cognitive } \\
\text { impairment } \\
\text { (time since CNS } \\
\text { mass lesions) }\end{array}$ & Final MRI features & $\begin{array}{l}\text { Vital status at } \\
\text { follow-up visit } \\
\text { [duration of } \\
\text { follow-up }^{\text {(years)] }}\end{array}$ \\
\hline 1 & 21 & 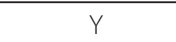 & $C R$ & $\mathrm{~N}$ & $\mathrm{~N}$ & & $\mathrm{DI}, \mathrm{GHD}$ & None & Normal & $L[9.0]$ \\
\hline 2 & 3 & $\mathrm{~N}$ & PD & $\begin{array}{l}\text { Y [therapy } \\
\text { withdrawn] }\end{array}$ & $N$ & & $\mathrm{Dl}$ & $\begin{array}{l}\text { NDS } \\
\text { (simultaneously) }\end{array}$ & $\begin{array}{l}\text { Neurodegenerative } \\
\text { lesions }\end{array}$ & $\mathrm{D}[4.4]$ \\
\hline 3 & 17 & $\mathrm{~N}$ & $C R$ & $\mathrm{~N}$ & $\mathrm{~N}$ & & Panhypopituitarism & $\begin{array}{l}\text { NDS (about } 1 \text { y } \\
\text { after mass lesion) }\end{array}$ & Atrophy & $L[6.8]$ \\
\hline 4 & 12 & $\mathrm{~N}$ & $P R$ & $N$ & $\mathrm{~N}$ & & $\begin{array}{l}\text { DI, GHD, obesity, } \\
\text { hypothalamic } \\
\text { syndrome }\end{array}$ & $\begin{array}{l}\text { Behavioral } \\
\text { disturbance - } \\
\text { several months } \\
\text { after the end of } \\
\text { therapy }\end{array}$ & Residual lesions $^{c}$ & $L[6.7]$ \\
\hline 5 & 13 & Y & SD & $\mathrm{N}$ & $\begin{array}{l}\text { Y [brain stem, } \\
\text { month 12] }\end{array}$ & $\begin{array}{l}\text { IC plus autograft } \\
\text { [resulting in PR, } \\
\text { subsequent death } \\
\text { from sepsis] }\end{array}$ & $\mathrm{Dl}$ & $\begin{array}{l}\text { NDS } \\
\text { (simultaneously) }\end{array}$ & $\begin{array}{l}\text { Tumoral lesion and } \\
\text { neurodegenerative } \\
\text { lesion }\end{array}$ & $\mathrm{D}[7.1]$ \\
\hline 6 & 13 & N & PR & $N$ & $\mathrm{~N}$ & & $\mathrm{Dl}$ & $\begin{array}{l}\text { NDS ( } 3 \text { years after } \\
\text { mass lesion) }\end{array}$ & $\begin{array}{l}\text { No tumoral lesion. } \\
\text { Neurodegenerative } \\
\text { lesions }\end{array}$ & $L[7.2]$ \\
\hline 7 & 18 & 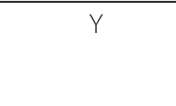 & SD & $\mathrm{N}$ & $\begin{array}{l}\text { Y [temporal } \\
\text { lobe, month } \\
\text { 16] }\end{array}$ & $\begin{array}{l}\text { VBL [death } 1 \text { month } \\
\text { after VBL] }\end{array}$ & $\mathrm{Dl}$ & $\begin{array}{l}\text { NDS } \\
\text { (simultaneously) }\end{array}$ & $\begin{array}{l}\text { Tumoral lesion and } \\
\text { neurodegenerative } \\
\text { lesion }\end{array}$ & $\mathrm{D}[4.4]$ \\
\hline 8 & 30 & Y & $P R$ & $N$ & $\begin{array}{l}\text { Y } \\
\text { [hypothalamus, } \\
\text { month 15] }\end{array}$ & VBL & $\mathrm{Dl}$ & None & Residual lesions $^{c}$ & $L[10.9]$ \\
\hline 9 & 12 & $\mathrm{~N}$ & SD & $N$ & $\mathrm{~N}$ & & $\mathrm{Dl}$ & None & Residual lesions $^{c}$ & $L[3.8]$ \\
\hline 10 & 18 & Y & $C R$ & $N$ & $\mathrm{~N}$ & & $\begin{array}{l}\text { Dl, morbid obesity, } \\
\text { hypothalamic } \\
\text { syndrome }\end{array}$ & None & Residual lesions $^{c}$ & $L[7.4]$ \\
\hline 11 & 7 & Y & $P R$ & $\mathrm{~N}$ & $\begin{array}{l}\text { Y } \\
\text { [hypothalamus, } \\
\text { month 19] }\end{array}$ & VBL [PR) & $\mathrm{DI}$ & None & Residual lesions $^{c}$ & $L[1.4]$ \\
\hline 12 & 6 & Y & SD & $N$ & $\begin{array}{l}\text { Y [brain stem, } \\
\text { month 47] }\end{array}$ & $\begin{array}{l}\text { 2-cda [relapse at } 5 \\
\text { months] Subsequent } \\
\text { treatment with } \\
\text { autograft [CR/ } \\
\text { remission] }\end{array}$ & $\mathrm{DI}$ & None & Residual lesions $^{c}$ & $L[8.3]$ \\
\hline 13 & 10 & Y & PR & $N$ & & & $\mathrm{Dl}$ & None & Normal & L [10.0] \\
\hline 14 & 12 & $N$ & $P R$ & $N$ & $\begin{array}{l}\text { Y } \\
\text { [hypothalamus } \\
\text { month 3] }\end{array}$ & $\begin{array}{l}\text { VBL, [VBL allergy }{ }^{\mathrm{b}} \text { ] } \\
\text { Then RT [failure], then } \\
\text { 2-cda [CR] }\end{array}$ & Panhypopituitarism & None & Residual lesions $^{c}$ & $L[10.9]$ \\
\hline
\end{tabular}


Table 2 Response to treatment and outcome (Continued)

\begin{tabular}{|c|c|c|c|c|c|c|c|c|c|c|}
\hline 15 & 12 & $Y$ & PR & $\mathrm{N}$ & & & $\mathrm{DI}, \mathrm{GHD}$ & None & Normal & $L$ [21.3] \\
\hline 16 & 5 & $\mathrm{Y}$ & $C R$ & $\mathrm{~N}$ & $\begin{array}{l}\text { Y [brainstem, } \\
\text { month 20] }\end{array}$ & $\begin{array}{l}\text { 2-cda [frank } \\
\text { progression leading } \\
\text { to death] }\end{array}$ & $\mathrm{Dl}$ & $\begin{array}{l}\text { Cognitive } \\
\text { impairment - } \\
\text { progressive after } \\
\text { end of initial } \\
\text { therapy }\end{array}$ & $\begin{array}{l}\text { Disease progression } \\
\text { (to brain stem) }\end{array}$ & $\mathrm{D}[1.9]$ \\
\hline 17 & 12 & $\mathrm{Y}$ & $P R$ & $\mathrm{~N}$ & Y [bone only) & VBL plus steroid & $\mathrm{DI}$ & None & Residual lesions ${ }^{c}$ & $L[7.3]$ \\
\hline 18 & 4 (ongoing) & $\mathrm{Y}$ & $P R$ & $\mathrm{~N}$ & $\mathrm{~N}$ & & $\mathrm{Dl}$ & None & Residual lesions ${ }^{c}$ & $L[0.4]$ \\
\hline 19 & 12 & $\bar{Y}$ & $P R$ & $\mathrm{~N}$ & $\mathrm{~N}$ & & Panhypopituitarism & None & Residual lesions ${ }^{c}$ & $L[5.0]$ \\
\hline 20 & 11 & $\mathrm{Y}$ & $C R$ & $\mathrm{~N}$ & $N$ & & None & None & Normal & $L[6.9]$ \\
\hline
\end{tabular}

2-cda $=$ 2-chlorodeoxyadenosine, $\mathrm{CR}=$ complete response, $\mathrm{D}=$ deceased; $\mathrm{DI}=$ central diabetes insipidus, $\mathrm{IC}=$ intensive chemotherapy, $\mathrm{GHD}=$ growth hormone deficiency, $\mathrm{L}=$ living; $\mathrm{MRI}=$ magnetic resonance

imaging; $\mathrm{N}=$ no, $\mathrm{NDS}=$ neurodegenerative syndrome; $\mathrm{PD}=$ progressive disease, $\mathrm{PR}=$ partial response, $\mathrm{RT}=$ radiotherapy, $\mathrm{SD}=$ stable disease, $\mathrm{VBL}=$ vinblastine, $\mathrm{Y}=$ yes.

a The duration of treatment is calculated from the start of VBL to the end of the maintenance treatment, i.e. the last pulse of VBL and/or the last steroid dose.

${ }^{b}$ Repeated skin risk after VBL pulses, increasing after repeated injections.

c Residual lesion are considered if the mass lesion remained unchanged during sequential MRI at least during a 6-month interval.

d Duration is calculated from the time of diagnosis of CNS mass lesions. 

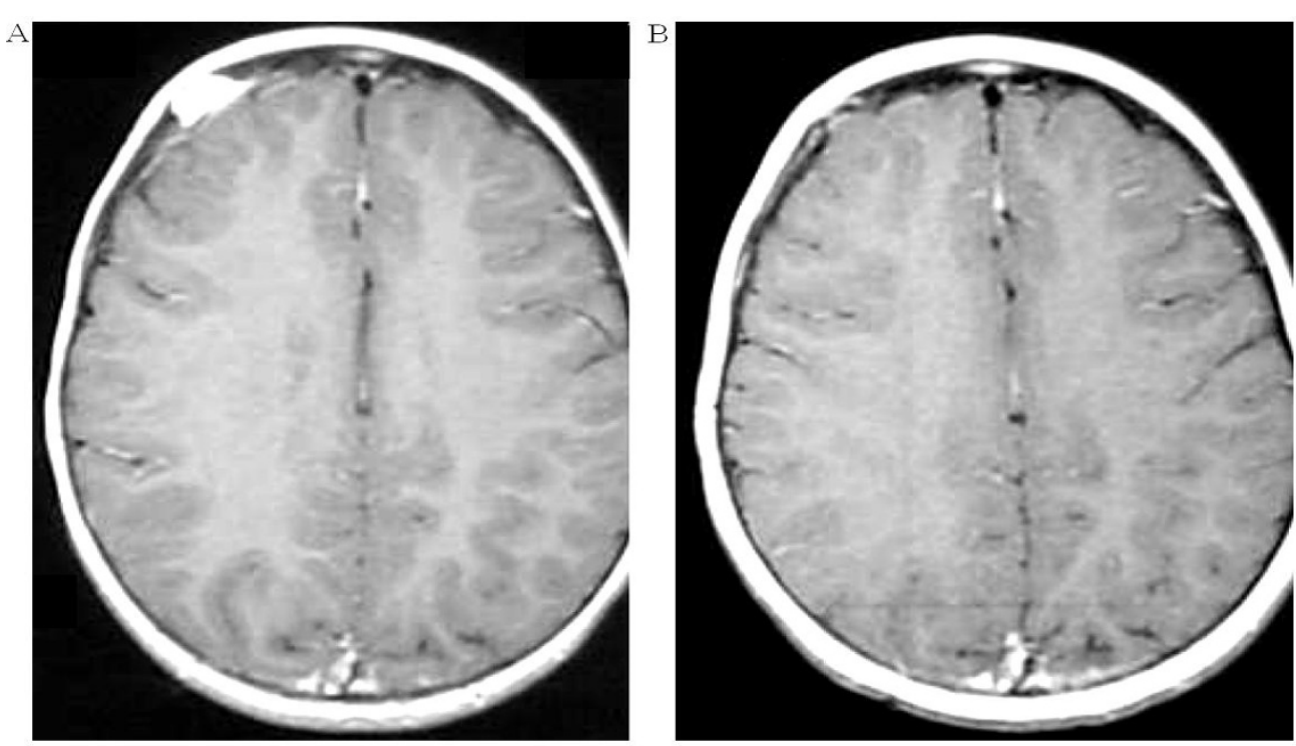

Figure 1 Complete response to vinblastine chemotherapy. Dura mater lesion. Axial T1-weighted magnetic resonance imaging (MRI) with gadolinium before treatment with vinblastine (A) and 8 months after treatment initiation showing a complete response (B).

chemotherapy and responded, one patient underwent radiotherapy but with no improvement, but did respond thereafter to treatment with 2 -cda. Two patients responded to an intensive chemotherapy regimen with hematopoietic stem cell support (the latter after failure of 2-cda treatment) but one among the two died from complications of neurodegenerative CNS LCH. Finally one patient did not respond to 2-cda treatment and experienced rapid tumoral progression leading to death.

The 5 -year overall survival rate was $84 \%$ (95\% CI: 58 94\%). Four patients died, at 1, 14, 21 and 24 months after the initiation of VBL treatment. Of note, three of these patients ( $2 \# 5 \# 16 \#)$ had a mass lesion in the brainstem and two (patient $2 \#$ and 5\#) had bilateral non-enhancing lesions of the cerebellum white matter. The immediate cause of death was a pulmonary embolism $(n=1)$ (patient 7\#), sepsis $(\mathrm{n}=1)$ (patient $5 \#)$ and neurologic disease progression $(\mathrm{n}=2)$ (patient $5 \#$ and 16\#). Endocrine sequelae were observed in 19 patients: with central diabetes insipidus (CDI) in 19 patients, growth hormone deficiency in 6 patients and panhypopituitarism in 3 patients. CDI was always present at the diagnosis of CNS
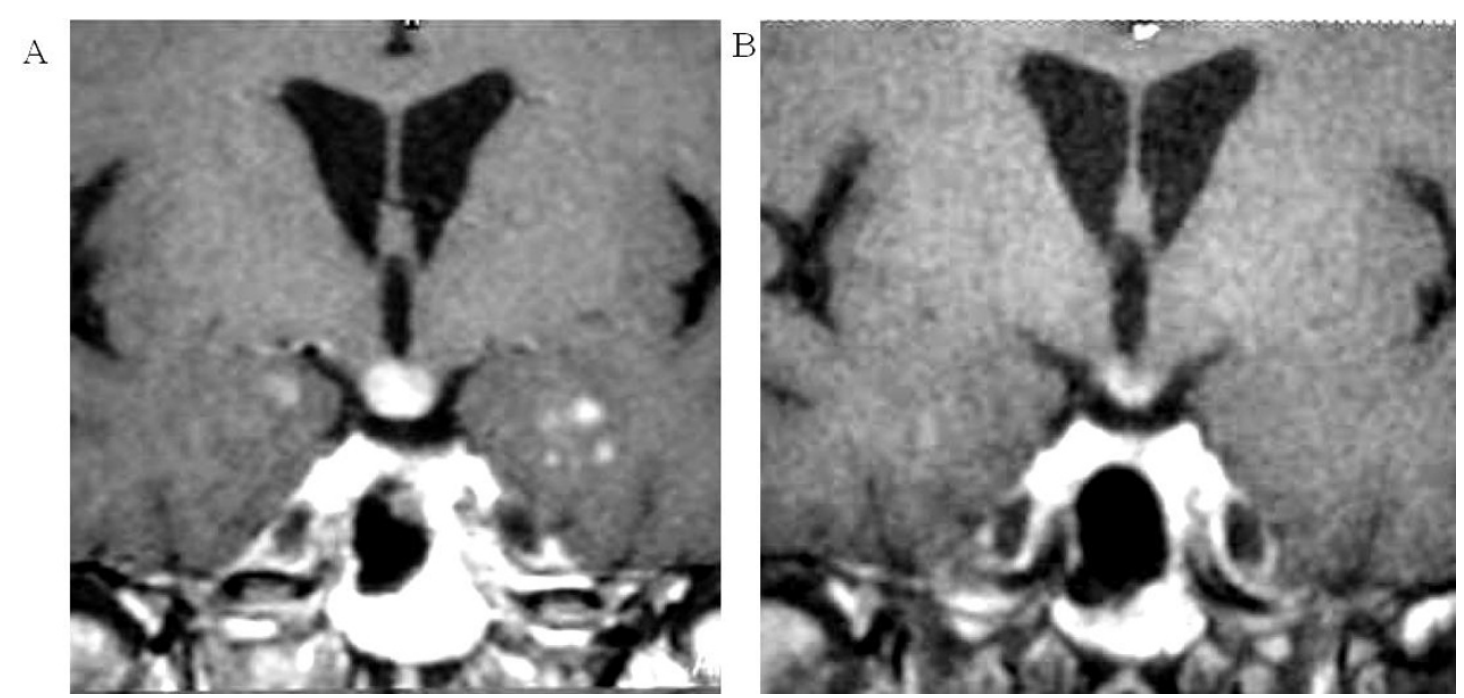

Figure 2 Partial response to vinblastine chemotherapy. Hypothalamic and temporal lesions. Coronal T1-weighted magnetic resonance imaging (MRI) with gadolinium before treatment with vinblastine (A) and 12 months after treatment initiation, showing a partial response (B). 

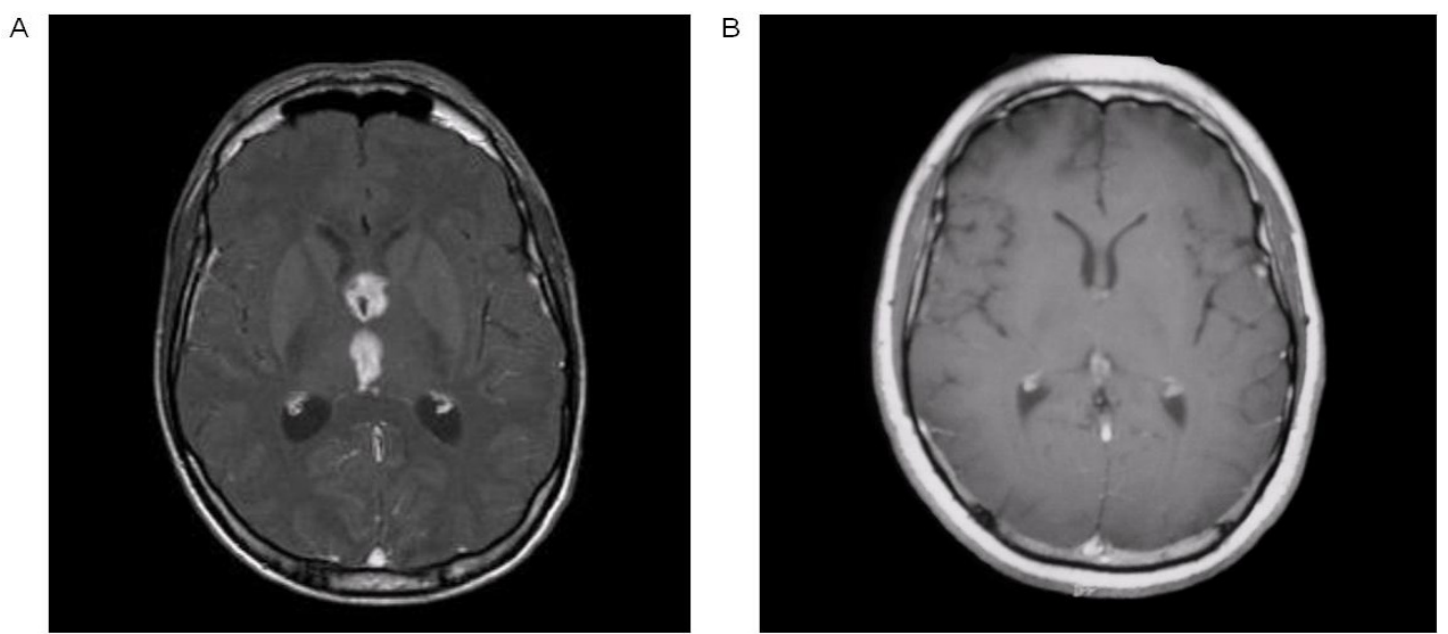

Figure 3 Complete response to vinblastine chemotherapy. Third ventricle lesion. Axial T1-weighted magnetic resonance imaging (MRI) with gadolinium before vinblastine treatment (A) and 6 months after treatment initiation, showing a complete response (B).

mass lesions and persisted, even in the case of CR. The age of patients at diagnosis, specifically those over 18 years old, was associated with a poorer outcome compared with those younger than 18 years old, both in terms of event-free survival (5-year event-free survival rates of $28 \%$ vs $90 \%$; $p=0.005$ ) and overall survival (5year overall survival rate of $57 \%$ vs $100 \% ; \mathrm{p}=0.0052$ ).

\section{Discussion}

Among 20 patients with LCH and CNS mass lesions, a $75 \%$ objective response rate was observed following VBL chemotherapy. Because the majority of patients received steroids at the same time (as an anti-inflammatory or as part of their chemotherapy regimen), it is difficult to attribute the treatment response solely to VBL. However, in the subgroup if patients who did not receive any steroids in their initial treatment, the objective response rate was comparable with the overall response rate of the steroid-treated group (2/3 of the patients i.e. 4 responders out of 6 patients). This suggests that VBL, either as monotherapy or in combination with steroids, is highly active in LCH with CNS mass lesions. Additionally,

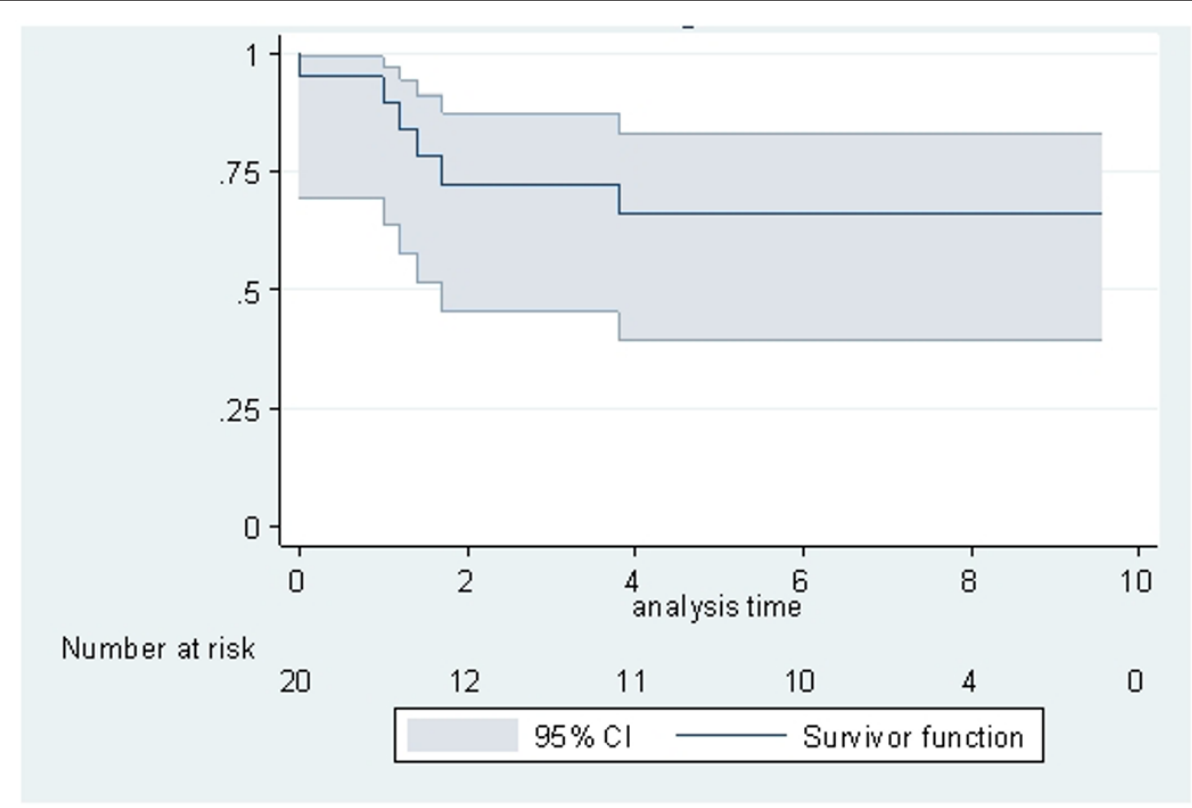

Figure 4 Event-free survival calculated by the Kaplan-Meier method. Events are progressive disease or any new progression after initial control of the CNS lesion. Duration is expressed in years. 
patients who respond do not appear to become desensitized to VBL over time: three patients who relapsed after VBL treatment were successfully retreated at recurrence with the same VBL regimen. Our results confirm and extend those of case reports; an objective response to VBL as primary or salvage therapy was observed in four out of five patients in $\mathrm{LCH}$ with CNS mass lesions [21-25]. Contrary to its effect on mass lesions, VBL seems to have no effect on neurodegenerative lesions and their related symptoms, which seem to arise via pathophysiologic mechanisms distinct from CNS mass lesions [7]. Interestingly, the patients in this study that demonstrated a mixed form of $\mathrm{LCH}$ worsened.

VBL, a vinca alkaloid, is a key drug in the treatment of multisystem $\mathrm{LCH}$, where response rates of up to $70 \%$ have been achieved $[17,26]$, which is comparable with the response rate observed in our present study for CNS mass lesions. This suggests that VBL penetrates the blood-brain barrier sufficiently so as to have a therapeutic effect on CNS mass lesions. In addition, VBL is well tolerated and can be delivered for a prolonged time without significant cumulative toxicity, as observed in the present study and elsewhere [26].

The purine substrate analogue 2-cda has been also been shown to be similarly effective for systemic LCH [27], but it is widely considered more appropriate as a second-line therapy [28]. Paradoxically, its use has been more frequently reported than the use of VBL in patients with CNS mass lesions: Dhall et al reported a series of 12 patients treated with 2-cda who achieved an objective response (8 CR and $4 \mathrm{PR}$ ) [29]. Similarly to the patients in this study, those in the Dhall group had CNS lesions primarily in the hypothalamo-pituitary region $(\mathrm{n}=10)$, while the remaining two patients had extra-hypothalamic lesions located in the dura mater. While 2-cda treatment yielded a high response rate, it was also associated with substantial toxicity, especially prolonged bone marrow suppression previously described in other studies [30]. In light of this, 2-cda would be likely to be best utilized as second-line chemotherapy after VBL in relapsed or treatment-refractory patients. Anecdotal cases of LCH with CNS mass lesions treated with intensive chemotherapy plus hematopoietic stem cell support have been reported, with a prolonged response observed in some patients, but absence of response in others [31].

\section{Conclusion}

Our results suggest that VBL is a therapeutic option for CNS mass lesions in $\mathrm{LCH}$, and support the continued evaluation of VBL in prospective trials. Chemotherapy with VBL appears to be of particular interest for the treatment of lesions in non-operable locations, multifocal lesions or secondary CNS lesions in the setting of systemic active $\mathrm{LCH}$ disease.

\section{Acknowledgements}

We thank Tracy Harrison of inScience Communications, a Wolters Kluwer business, who provided assistance with English-language editing after peer review. This assistance was funded by the Groupe d'Etude des Histiocytoses and by a grant from the Association Histiocytose France. The French Histiocytosis register is funded by the Institute de Veille Sanitaire and Inserm.

\section{Author details}

${ }^{1}$ APHP-UPMC, Service de neurologie 2-Mazarin, Groupe Hospitalier PitiéSalpêtrière, Paris, France. ${ }^{2}$ Service de neuroradiologie, Groupe Hospitalier Pitié-Salpêtrière, Paris, France. ${ }^{3}$ Service de radiologie, Hôpital Trousseau, Paris, France. ${ }^{4}$ Commissariat à l'énergie atomique, Orsay, France. ${ }^{5}$ Service hématoOncologie pédiatrique, Hôpital Trousseau, Paris, France. ${ }^{6}$ Unité d'oncologie pédiatrique, centre Oscar-Lambret, Lille, France. ${ }^{7}$ Service d'hématologie pédiatrique, CHU de Lille, Lille, France. ${ }^{8}$ Centre de référence des histiocytoses, Registre des histiocytoses, Service d'hémato oncologie pédiatrique, Hôpital Trousseau, Paris, France. ${ }^{9}$ Service Hémato - Oncologie Pédiatrique CHU Reims, France. ${ }^{10}$ Service Hémato - Oncologie Pédiatrique $\mathrm{CHU}$ Angers, France. ${ }^{11}$ Service de rhumatologie, Centre national de références des maladies auto-immunes systémiques, hôpital de Hautepierre, $\mathrm{CHU}$ de Strasbourg, France. ${ }^{12}$ Service de pédiatrie, $\mathrm{CHU}$ de Strasbourg, France. ${ }^{13}$ Service de médecine interne, hôpital Béclère, Clamart, France. ${ }^{14}$ Service d'endocrinologie pédiatrique, Hôpital Necker APHP, France. ${ }^{15}$ Service d'hémato oncologie Pédiatrique CHU Purpan Toulouse, France. ${ }^{16}$ Service de médecine interne, $\mathrm{CHU}$ de Clermont-Ferrand, France. ${ }^{17}$ Unité d'hémato Oncologie Pédiatrique $\mathrm{CHU}$ de Grenoble, France. ${ }^{18}$ Médecine Interne, Nouvelle Clinique Nantaise, Nantes, France. ${ }^{19}$ Institut d'hémato Oncologie Pédiatrique CHU de Lyon, France. ${ }^{20}$ Polyclinique de Deauville, 14113 Cricqueboeuf, France. ${ }^{21}$ Service de médecine interne, $\mathrm{CHU}$ de Reims, France. ${ }^{22}$ Neurologie pédiatrique, hôpital Clocheville, CHRU Tours, France. ${ }^{23}$ Service de pédiatrie, CHRU de Dijon, France. ${ }^{24}$ Service de médecine interne, Groupe Hospitalier Pitié-Salpêtrière, Paris, France. ${ }^{25}$ Service de neuropathologie, Groupe Hospitalier Pitié-Salpêtrière, Paris, France.

\section{Authors' contributions}

SNWT analyzed the data and wrote the manuscript. NMD, Al, CG, MR, JLP, $A S D, A L, M B, M M, M G, J S, P L, R F, M P, A R, O A, D P, C A, G C, T G, P M B, G N T, J L P$, $H D P, M A B, J H$, and $K M$ revised the manuscript. JD designed the study, analyzed the data and revised the manuscript. KHX designed the study and revised the manuscript. All authors read and approved the final manuscript.

\section{Competing interests}

The authors declare that they have no competing interests.

Received: 19 June 2011 Accepted: 12 December 2011

Published: 12 December 2011

\section{References}

1. Senechal B, Elain G, Jeziorski E, Grondin V, Patey-Mariaud de SN, Jaubert F, et al: Expansion of regulatory $T$ cells in patients with Langerhans cell histiocytosis. PLoS Med 2007, 4:e253.

2. Arico M, Girschikofsky M, Genereau T, Klersy C, McClain K, Grois N, et al: Langerhans cell histiocytosis in adults. Report from the International Registry of the Histiocyte Society. Eur J Cancer 2003, 39:2341-2348.

3. Howarth DM, Gilchrist GS, Mullan BP, Wiseman GA, Edmonson JH, Schomberg PJ: Langerhans cell histiocytosis: diagnosis, natural history, management, and outcome. Cancer 1999, 85:2278-2290.

4. The French Langerhans' Cell Histiocytosis Study Group: A multicentre retrospective survey of Langerhans' cell histiocytosis: 348 cases observed between 1983 and 1993. Arch Dis Child 1996, 75:17-24.

5. Grois N, Fahrner B, Arceci RJ, Henter Jl, McClain K, Lassmann H, et al: Central nervous system disease in Langerhans cell histiocytosis. J Pediatr 2010, 156:873-81, 881.

6. Komp DM: Long-term sequelae of histiocytosis X. Am J Pediatr Hematol Oncol 1981, 3:163-168.

7. Grois N, Prayer D, Prosch H, Lassmann H: Neuropathology of CNS disease in Langerhans cell histiocytosis. Brain 2005, 128:829-838.

8. Idbaih A, Donadieu J, Barthez MA, Geissmann F, Bertrand Y, Hermine O, et al: Retinoic acid therapy in "degenerative-like" neuro-langerhans cell histiocytosis: a prospective pilot study. Pediatr Blood Cancer 2004, 43:55-58. 
9. Imashuku S, Shioda Y, Kobayashi R, Hosoi G, Fujino H, Seto S, et al: Neurodegenerative central nervous system disease as late sequelae of Langerhans cell histiocytosis. Report from the Japan LCH Study Group. Haematologica 2008, 93:615-618.

10. Martin-Duverneuil N, Idbaih A, Hoang-Xuan K, Donadieu J, Genereau T, Guillevin R, et al: MRI features of neurodegenerative Langerhans cell histiocytosis. Eur Radiol 2006.

11. Prayer D, Grois N, Prosch H, Gadner H, Barkovich AJ: MR imaging presentation of intracranial disease associated with Langerhans cell histiocytosis. AJNR Am J Neuroradiol 2004, 25:880-891.

12. Ribeiro MJ, Idbaih A, Thomas C, Remy P, Martin-Duverneuil N, Samson $Y$, et al: (18)F-FDG PET in neurodegenerative Langerhans cell histiocytosis: Results and potential interest for an early diagnosis of the disease. $J$ Neurol 2008

13. Barthez MA, Araujo E, Donadieu J: Langerhans cell histiocytosis and the central nervous system in childhood: evolution and prognostic factors. Results of a collaborative study. J Child Neurol 2000, 15:150-156.

14. Gagel O: Granulationsgeschwulst im Gebiet des Hypothalamus. Z Neurol 1941, 172:710-722

15. Gizewski ER, Forsting M: Histiocytosis mimicking a pineal gland tumour. Neuroradiology 2001, 43:644-646.

16. Goldberg R, Han JS, Ganz E, Roessman U: Computed tomography demonstration of multiple parenchymal central nervous system nodules due to histiocytosis X. Surg Neurol 1987, 27:377-380.

17. Gadner H, Grois N, Arico M, Broadbent V, Ceci A, Jakobson A, et al: A randomized trial of treatment for multisystem Langerhans' cell histiocytosis. J Pediatr 2001, 138:728-734.

18. Guyot-Goubin A, Donadieu J, Barkaoui M, Bellec S, Thomas C, Clavel J: Descriptive epidemiology of childhood Langerhans cell histiocytosis in France, 2000-2004. Pediatr Blood Cancer 2008, 51:71-75.

19. Favara BE, Feller AC, Pauli M, Jaffe ES, Weiss LM, Arico M, et al: Contemporary classification of histiocytic disorders. The WHO Committee On Histiocytic/Reticulum Cell Proliferations. Reclassification Working Group of the Histiocyte Society. Med Pediatr Oncol 1997, 29:157-166.

20. Macdonald DR, Cascino TL, Schold SC Jr, Cairncross JG: Response criteria for phase II studies of supratentorial malignant glioma. J Clin Oncol 1990, 8:1277-1280.

21. Allard P, Kermarec J, Goasguen J, Ferry M, de Muizon H, Girard P, et al: [Cerebral and pulmonary histiocytosis X. Neurologic manifestations disclosing a pseudotumoral formation on the floor of the 4 th ventricle]. Rev Pneumol Clin 1984, 40:305-309.

22. Carpentier MA, Maheut J, Grangeponte MC, Billard C, Santini JJ: Disseminated cerebral histiocytosis $X$ responding to vinblastine therapy: a case report. Brain Dev 1991, 13:193-195.

23. Gavriel H, Shuper A, Kornreich L, Goshen Y, Yaniv I, Cohen IJ: Diffuse intrinsic brainstem disease with neurologic deterioration: not what it seemed. Med Pediatr Oncol 2000, 34:213-214.

24. O'Sullivan RM, Sheehan M, Poskitt KJ, Graeb DA, Chu AC, Joplin GF: Langerhans cell histiocytosis of hypothalamus and optic chiasm: CT and MR studies. J Comput Assist Tomogr 1991, 15:52-55.

25. Pierrot-Deseilligny $C$, Goasguen J: Isolated abducens nucleus damage due to histiocytosis X. Electro-oculographic analysis and physiological deductions. Brain 1984, 107:1019-1032.

26. Lafay-Cousin L, Holm S, Qaddoumi I, Nicolin G, Bartels U, Tabori U, et al: Weekly vinblastine in pediatric low-grade glioma patients with carboplatin allergic reaction. Cancer 2005, 103:2636-2642.

27. Saven A, Burian C: Cladribine activity in adult langerhans-cell histiocytosis. Blood 1999, 93:4125-4130.

28. Weitzman S, Braier J, Donadieu J, Egeler RM, Grois N, Ladisch S, et al: 2'Chlorodeoxyadenosine (2-CdA) as salvage therapy for Langerhans cell histiocytosis (LCH). results of the LCH-S-98 protocol of the Histiocyte Society. Pediatr Blood Cancer 2009, 53:1271-1276.

29. Dhall G, Finlay JL, Dunkel IJ, Ettinger LJ, Kellie SJ, Allen JC, et al: Analysis of outcome for patients with mass lesions of the central nervous system due to Langerhans cell histiocytosis treated with 2chlorodeoxyadenosine. Pediatr Blood Cancer 2008, 50:72-79.

30. Yamada K, Yasui M, Sawada A, Inoue M, Nakayama M, Kawa K: Severe persistent bone marrow failure following therapy with 2 chlorodeoxyadenosine for relapsing juvenile xanthogranuloma of the brain. Pediatric Blood \& Cancer 2011, doi: 10.1002/pbc.23087.
31. Gaspar N, Boudou P, Haroche J, Wechsler B, Van Den NE, Hoang-Xuan K, et al: High-dose chemotherapy followed by autologous hematopoietic stem cell transplantation for adult histiocytic disorders with central nervous system involvement. Haematologica 2006, 91:1121-1125.

doi:10.1186/1750-1172-6-83

Cite this article as: $\mathrm{Ng}$ Wing Tin et al:: Efficacy of vinblastine in central nervous system Langerhans cell histiocytosis: a nationwide retrospective study. Orphanet Journal of Rare Diseases 2011 6:83.

\section{Submit your next manuscript to BioMed Central and take full advantage of:}

- Convenient online submission

- Thorough peer review

- No space constraints or color figure charges

- Immediate publication on acceptance

- Inclusion in PubMed, CAS, Scopus and Google Scholar

- Research which is freely available for redistribution

Submit your manuscript at www.biomedcentral.com/submit
Biomed Central 